ing boards have visited the libraries directly or indirectly under their jurisdiction. What image do trustees have of their librarians? Do they think of them as the book-fetching and date-stamping set one met at a public library desk in the days of yore?

It may be argued that there is little pertinence in these questions because governing boards are but rubber-stamping agencies for the college president's decisions. Dr. Beck points out that this is far from true especially in matters of budget allocation. Trustee interference in the matter of appointments must also be taken into account: There is also the question of academic freedom which has on occasion reared its ugly head in the annals of librarianship. For those whose primary interest is in endowed research libraries, the problems which are discussed in this book must have even greater immediacy. - Sidney Ditzion, College of the City of New York Library.

\title{
International Exchanges
}

American Library Association. Board of Resources of American Libraries and International Relations Board: Conference on International Cultural, Educational and Scientific Exchanges, Princeton University, November 25-26, 1947. Preliminary Memoranda. Recommendations Adopted; Summary of Discussion. By Edwin E. Williams [and] Ruth V. Noble. Chicago, American Library Association, 1947. xxii, 2 lop.

In the autumn of 1839 there arrived in the United States a Frenchman "of rather under the medium size, spare, with long hair, sparkling eyes, and an energy of gesticulation which," said a contemporary, "accords well with his animated countenance." This man was imbued with an idea, and it was admitted that "everybody with whom he converses becomes enlisted in his project, nor is it possible to withstand his earnest arguments, which evidently come direct from the heart." The subject of this description was Alexandre Vattemare, and his idea was to promote the international exchange of publications. "Intelligence diffused and everywhere accessible!" was his battle cry. The art of printing, through which intelligence is diffused and made accessible, was for him nothing less than "that mighty engine which has established the future liberty of the human race." His own job was to promote the diffusion and the accessibility.

The story of the immediate and enduring benefits to American scholarship which resulted from Vattemare's visit composes a well-known chapter in American library history (it is summarized and adequately docu- mented in the work under notice), and his memorial to Congress in 1839 is often cited. The present work promises to become a landmark of at least equal prominence. Superficially, it is the record of a two day conference at Princeton in the autumn of 1946 , attended by thirty-two librarians and others, to discuss the whole matter of exchanges. The idea for the conference and the supporting studies was originally conceived by Carl $\mathrm{H}$. Milam. The meeting was sponsored by the Board on Resources and the International Relations Board of the American Library Association. The preliminary work as well as the publication of the results were made possible by the Carnegie Corporation. That the conference was related to the work of UNESCO is evident from its title. (Actually, since the interest of the conference was restricted to library exchanges, the title is a trifle misleading.) The charter of UNESCO specifically mentions international exchanges as one of the objects which it will promote in the interest of peace. The question put to the Princeton conference, therefore, was "how the highly significant aims can be most effectively achieved."

To the Princeton conferees the subject of exchanges was no longer the simple matter that it was to Vattemare. In the one hundred nine years which have elapsed since the publication of his memorial, the simple concept of exchange of publications has become entangled with a multitude of dependent and ancillary considerations. It is a chief merit of the present work that it has assembled, disentangled, and brought order into these various considerations. The lapse of time has 
caused, too, some shifting of emphasis, and has somewhat mixed the motives. "Of all the countries in the world," Vattemare maintained, "America will have the most to gain in entering into this plan." The present work assumes that the United States has at least as much to give as to gain, has at the very least an obligation to take the initiative in developing arrangements; and as a sad commentary on human "progress," contains a chapter devoted to rehabilitation of wardevastated libraries.

It is interesting to find, however, that the stakes are the same for the librarians at Princeton as they were for Vattemare, though differently expressed. To the Princeton conferees the ultimate objectives were "society's progress," "international understanding, fundamental to international good will," and "intelligent and informed world opinion." To Vattemare the objective was nothing less than "the future liberty of the human race." The difference is one of tone. The record of the Princeton conference is a sober book, feeling its way through a difficult set of library problems. It was not appropriate that it should use the rhetoric which leaped so facilely to Vattemare's lips. But while this book lacks the missionary fervor with which Vattemare so quickly won support for his idea, it does not lack an exciting quality of its own. It is the exciting quality which is felt when a mass of hitherto imperfectly related details is found to have been brought together so as for the first time to present a view of this whole. This statement refers not to the record of the discussions of the conference, but to the preparatory material, which as now presented in this volume makes a permanent contribution to library literature.

The agenda for the conference were arranged under twelve principal subjects. It will probably be agreed that a better choice, from the point of view of getting discussion on fundamental problems and avoiding the side issues and the trivial, could not have been made. Each of these subjects was then made the topic of a summarizing memorandum prepared by Edwin E. Williams, of the staff of the Harvard College Library, and Ruth V. Noble. The object of the memorandum was in each case to bring together in a rapid survey a record of the previous activity, accomplishments, and proposals in the field; to point out the principal unresolved problems; and to raise pertinent questions which might stimulate the discussions of the conference. The effect of this-treatment was to provide an admirable historical perspective, in condensed yet adequate and documented form, of the subjects under discussion. In some cases this perspective reached back for several centuries. In others, it brought into view proposals so recent that papers on the subject were still lying unpublished on the desks of the conferees at the date of the conference. Admirable, too, is the effectiveness with which this treatment placed the various parts of the subject in essential relationship to each other. It is not inappropriate, therefore, that of the entire volume before us, less than a third is devoted to the conference itself, and more than two thirds to the Williams-Noble memoranda. Altogether, the preparatory work for the Princeton conference forms the best preparation for any library meeting, and the most continuingly useful compilation of the kind that this reviewer has seen.

The scope of the study, and the extent to which it exposed the conference to a consideration of fundamental problems, is indicated by the twelve topics selected as subjects for the memoranda. These were: author bibliography, subject bibliography, interlibrary loan, photographic reproduction, cooperative asquisition and specialization, international exchange of documents, exchanges between libraries, international commercial exchanges, barriers to international exchange, exhibits, international exchange of (library) personnel, rehabilitation; and a final discussion of agencies and priorities. It is obvious that, for such an agenda, the two days of the conference itself allowed meager scope for discussion.

At the termination of its necessarily concentrated consideration, the conference adopted twenty-four resolutions. Of these, five dealt with fundamental problems in bibliographic control; three, matters relating to union catalogs and the recording or concentration of library resources; three with various problems and applications of photographic reproduction, including copyright and interlibrary loan; three with cooperative acquisitions; three with the exchange of library 
materials, exhibits and personnel; two with the state department information libraries; three with the elimination of barriers to exchange; and two with the work of coordinating agencies in the field of exchanges and documentation. Of the latter, one was concerned with the work of the American Documentation Institute and the International Federation of Documentation, and one dealt with a proposal of Dr. Julian P. Boyd that there be established, in conjunction with the U. S. National Commission for UNESCO, a national educational, scientific, and cultural authority. The various recommendations were directed to a number of agencies: to the A.L.A. (5), A.R.L. (4), UNESCO or the U.S. National Commission for UNESCO (5), the Department of State and the $\mathrm{Li}$ brary of Congress ( 4 each), the Congress, the armed services, the Treasury Department, the American Book Center, and the Library of Congress Planning Committee (I each), besides three expressions of opinion without definite recommendations to a par- ticular body.

The readers of the proceedings of the Princeton conference deserve to be informed what progress has been made, during the year and a half which it has required to print its transactions, in executing its recommendations. It is gratifying to know that if a report of progress were to be made at the present time, it would show that few of the recommendations have not had or are now failing to receive serious attention, and that some are actually in process of accomplishment. Nevertheless, it is to be hoped that a systematic report will soon be made available, showing not only just what has been done, but where, and the extent to which responsibility has been accepted for accomplishing what still remains to be done. The Princeton conference, if it already has some claim to be regarded as a landmark, will only prove usefully so if it is actively employed as a point from which to measure distance and direction.-Verner $W$. Clapp, Library of Congress.

\section{British Sources of Reference}

Britislt Sources of Reference and Information, a Guide to Societies, Works of Reference and Libraries. Compiled under the direction of a Committee of Aslib and edited by Theodore Besterman. London, published for the British Council by Aslib, 1947. 58p. This selective guide to the resources of British libraries supplements and by no means supersedes the ASLIB Directory of 1928. Even allowing for the latter's inclusion of information agencies other than libraries and its different organization resulting in some repetitive information, the older 425 page quarto volume contains information on more libraries and more special collections than the new slim octavo of 56 pages.

However, the new guide brings information to date, with its news of some former collections that were bombed and burned out of existence and, on the other hand, of collections which have increased in size, like the Manchester University Library, which appears to have doubled itself in the last twenty years. Notes on the facilities for photographic reproduction, and other services which li- braries are now prepared to offer, are also a welcome addition.

The general description of the British library system as a whole, with its efficient organization for a national lending service, and the accounts of the British library and book organizations, constitute a new and valuable introduction for the scholar, student, or librarian beginning or renewing acquaintance with the great bibliographical resources of Great Britain. It should be noted that certain Irish libraries which were included in the ASLIB Directory, published before the establishment of the independent sovereignty of Eire, are missing here. One will have to turn back to the old directory or the still older University and College Libraries, by Newcombe, for information about Trinity College Library, which is mentioned in the new guide only as one of the copyright libraries which does not lend books.

The arrangement of material differs from that of the old guide. Instead of an extensive list by subject of special collections, with a list of libraries arranged by city and 